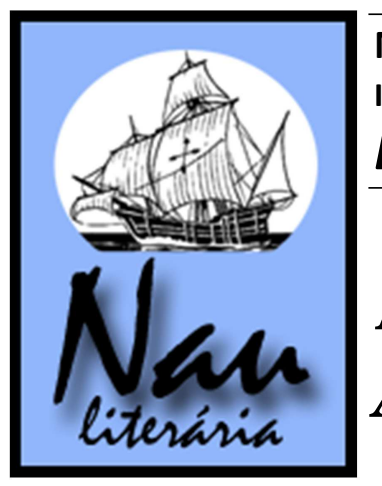

\title{
A recepção de $O$ crime do padre Amaro no Brasil do século XIX
}

\author{
Diógenes Caliari Armani*
}

\begin{abstract}
Resumo: Este artigo tem como objetivo analisar a recepção da obra $O$ Crime do Padre Amaro, de Eça de Queirós, no Brasil do século XIX. Para tal fim, o trabalho fundamenta-se nos princípios da corrente literária conhecida como Estética da Recepção, desenvolvida por Hans Robert Jauss na década de 1960. De acordo com a Estética da Recepção, uma mesma obra literária pode receber distintas valorações ao longo do tempo. Fatores históricos, sociais, geográficos, individuais estão diretamente relacionados à recepção de um autor e sua obra. Portanto, um romance, classificado como canônico em um determinado contexto, é passível de não receber a mesma canonização em contextos distintos.
\end{abstract}

Palavras-chave: Literatura; Estética da Recepção; $O$ Crime do Padre Amaro; Brasil do século XIX.

\begin{abstract}
This article intends to analize the reception of "O Crime do Padre Amaro", written by Eça de Queirós, in the Brazilian nineteenth century. In order to do that, this paper will be developed considering the Reception Aesthetics principles, developed by the German Hans Robert Jauss in the sixties. In accordance to the Aesthetics, a same literary work can receive different values throughout the times. Historical, social, geographical and individual factors are directly related to the author and their work reception. Therefore, a novel, classified as traditional in certain cases, cannot receive the same value in other contexts.
\end{abstract}

Keywords: Literature; Reception Aesthetics; O Crime do Padre Amaro; Brazilian nineteenth century.

\section{A Estética da Recepção}

Na década de 60, mais especificamente no ano de 1967, Hans Robert Jauss propõe, em aula inaugural na Universidade de Constança, inovações no que diz respeito ao campo da Literatura. A conferência exposta por Jauss é o marco inicial da corrente literária conhecida como Estética da Recepção. Antecedida, temporalmente, pelos princípios literários do formalismo russo, da nova crítica americana e do estruturalismo francês, para os quais o texto se convertia no objeto central de análise, a Estética da Recepção põe em cena o leitor. Este, a partir de agora, passa a ser visto como um personagem ativo no ato da leitura. "Em 1967, Hans Robert Jauss expôs a estética da recepção pela primeira vez, definindo-a como uma pesquisa sobre a recepção da literatura e seus efeitos no leitor e como uma superação do formalismo e do marxismo" (LOBO, 2001, p. 171).

A corrente alemã pode ser representada sob a seguinte estruturação:

\footnotetext{
${ }^{*}$ Graduando em Letras (UFRGS).
} 


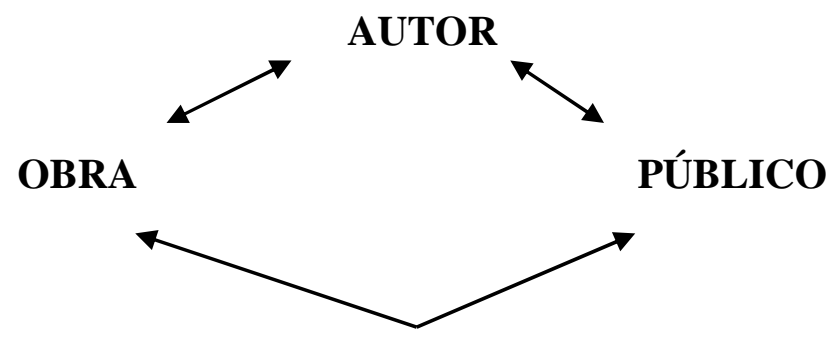

Em vista disso, uma mesma obra está sujeita a diversas interpretações e valorações, não somente originadas pelos leitores, mas também de acordo com o espaço temporal em que se situa, contexto histórico, camada social, etc. Segundo Lobo, uma nova estética é introduzida ao campo literário, visto que o objetivo da corrente alemã é romper com a análise puramente imanente ao texto praticada até então (LOBO, 2001, p. 172).

Além de introduzir uma nova metodologia de estudos na área literária, Jauss promove a subversão dos métodos tradicionais e/ou anacrônicos característicos dos estudos literários ocidentais:

A conferência com que Jauss abriu o ano acadêmico de 1967 ocorreu na Universidade de Constança, principal fruto da reforma educacional na Alemanha durante a segunda metade da década, é conhecida como "Provocação" e começa pela recusa vigorosa dos métodos de ensino da história da literatura, considerados tradicionais e, por isso, desinteressantes. (ZILBERMAN, 1989, p. 9)

Esse trabalho adota como horizonte a corrente literária da Estética da Recepção, visto que uma obra pode ser analisada sob diversas perspectivas, fazendo com que um autor e seus escritos estejam constantemente na fronteira entre o tradicional, ou canônico, e a literatura "periférica", ou de menor prestígio. Tudo dependerá da confluência harmônica de fatores temporais, sociais, históricos, subjetivos.

Para a análise da experiência do leitor ou da "sociedade de leitores" de um tempo histórico determinado, necessita-se diferenciar, colocar e estabelecer a comunicação entre os dois lados da relação texto e leitor. Ou seja, entre o efeito, como o momento condicionado pelo texto, como o momento condicionado pelo destinatário, para a concretização do sentido como duplo horizonte - o interno ao literário, implicado pela obra, e o multivivencial, trazido pelo leitor de uma determinada sociedade (COSTA LIMA, 1979, p.43).

A corrente literária desenvolvida por Jauss adota uma perspectiva sincrônica de análise. Portanto, a pesquisa aqui desenvolvida a respeito da obra $O$ Crime do Padre Amaro, de Eça de Queirós, delimita-se à recepção do público-leitor brasileiro (extremamente restrito) do século XIX, ou seja, um público deslocado, geograficamente, da obra em questão, porém contemporâneo ao texto produzido por Eça. 
20 Crime do Padre Amaro - Eça de Queirós

Amaro, ao subir as escadas, tremia - e, mal entrou na sala, o rosto de Amélia, alumiado pelas luzes do piano, deu-lhe um deslumbramento, como se as vésperas do noivado a tivessem embelezado, e a separação lha tornasse mais apetitosa.

O Crime do Padre Amaro representa o primeiro romance realista de língua portuguesa. A primeira edição da obra data de 1875. Eça de Queirós (1845-1871) foi alvo de severas críticas por parte da igreja católica. Durante décadas, a leitura da obra foi terminantemente proibida em escolas brasileiras e portuguesas.

A trama do romance centra-se na relação amorosa e secreta entre o padre Amaro Vieira e a jovem Amélia. Amaro, enviado ao seminário aos quinze anos de idade e com vocação duvidosa para o ofício religioso, posteriormente é nomeado pároco da Sé de Leiria, pequena cidade interiorana situada ao norte de Lisboa. De hospedagem na casa de Dona Joaneira, devota fervorosa, mãe de Amélia e amante do Cônego Dias, Amaro encanta-se pela jovem filha de sua anfitriã. A partir disso, a amizade entre Amaro e Amélia estreita-se gradualmente, , culminando no início de uma relação carnal entre ambos. Tramas e mentiras são arranjadas para que os encontros possam ocorrer, e o casal possa desfrutar os prazeres reprimidos na presença dos familiares de Amélia e dos colegas religiosos de Amaro.

A aventura amorosa resulta na gravidez de Amélia. Diante do desespero de ter sua reputação maculada, Amaro, logo após o parto de seu filho, entrega a criança à "tecedeira de anjos" Carlota, encarregada dos "cuidados" aos recém-nascidos indesejados que lhe são entregue. Amélia, devido a uma série de convulsões durante o parto, vem a falecer.

Sob o pretexto de que sua irmã está enferma, Amaro retorna a Lisboa e retoma sua rotina "eclesiástica”. Eis o enredo superficial da obra de Eça de Queirós que será abordada no presente trabalho, sob a perspectiva de recepção no contexto brasileiro dos anos 1800 .

\section{O Crime no Brasil do século XIX}

De acordo com Faro (1977, p.103), a data provável da divulgação de O Crime do Padre Amaro no Brasil foi o ano de 1876, ou seja, cerca de um ano após a primeira publicação da obra na Revista Ocidental, publicada em Lisboa. Essa revista circulou também no Brasil. No entanto, devido à pequena circulação, um público extremamente restrito obteve acesso aos exemplares de 1875. Segundo Faro, "a revista (Ocidental) aparecia quinzenalmente, e o romance foi publicado, sem interrupção, durante sete números, tendo terminado no de 15 de maio de 1875 . Constava de 22 capítulos e ocupou cerca de 160 
páginas" (p.102). Essa primeira versão da obra foi publicada sem a aprovação de Eça de Queirós, pois o autor estava descontente com a parte inicial de seu romance. Eça faria ainda duas modificações na obra: a primeira, em 1876, resultou em um volume de 362 páginas. A segunda modificação (ou terceira versão), editada em 1880, resultou em um volume definitivo contendo 674 páginas. Portanto, a primeira publicação de $O$ crime do padre amaro no Brasil, registrada em um periódico paulista intitulado A República das Letras, foi baseada na primeira versão, publicada na Revista Ocidental. A República das Letras apresentou-se com "o ensaio de um gênero ainda não cultivado entre nós, um periódico puramente literário, de intuitos exclusivamente artísticos" (FARO, 1977, p.104). O primeiro exemplar da revista é de 2 de abril de 1876, composto por quinze páginas e vendido por 200 réis. A publicação d' $O$ Crime do Padre Amaro teve inicio no terceiro número da revista, que data de 22 de abril de 1876. No entanto, não houve uma continuidade regular do periódico:

Eça de Queirós aparece na fase inicial (da revista), no n 3 , ou seja, no de 22 de abril de 1876. Nele, sem qualquer palavra de introdução, se principiou a publicar $O$ Crime do Padre Amaro, segundo a versão divulgada pela Revista Ocidental. O romance continuou nos números 4 e 5. Não prosseguiu, porém, na segunda fase (da revista). (...) O trecho do Padre Amaro publicado naqueles três números foi bastante curto. Dos 22 capítulos de que então se compunha o romance, apenas houve a transcrição do primeiro e de quase todo o segundo. (FARO, 1977, p.105).

Em 1890, no Rio de Janeiro, O crime do Padre Amaro recebe adaptação para o teatro. Uma década antes, o teatrólogo português Furtado Coelho havia fundado o Teatro Lucinda, e "foi nele que estreou, numa sexta-feira, 25 de abril de 1890, O crime do Padre Amaro, drama em seis atos e sete quadros, extraído do romance de Eça de Queirós. (...) Escreveu-a (a peça) Augusto Fabregas, teatrólogo e colaborador de $O$ País. Tinha ainda a adaptação um número musical de Francisca Gonzaga" (p. 200). Contudo, essa adaptação do Crime para os palcos recebeu críticas duras por parte de jornalistas e de escritores. Olavo Bilac, na época colaborador na Gazeta de Notícias, argumenta que "não espere o Sr. Fabregas que Eça de Queirós o absolva do seu crime”. Artur Azevedo, colaborador do jornal Correio do Povo, considerou a peça "uma farsalhada", além de obscena. Para grande parte da crítica, Fabregas havia cometido um crime mais condenável que o do próprio padre Amaro. Há que se mencionar também a notória inimizade entre Fabregas e Artur Azevedo.

Em 1887 Fabregas e o ator Bernardo Lisboa haviam apresentado, sob pseudônimos, na Fênix Dramática, a revista "Há alguma diferença?", na qual eram atacados outros escritores teatrais, especialmente Artur Azevedo, Moreira Sampaio e Valentim Magalhães. O primeiro era mesmo posto em cena, na pele de um personagem designado como Carioca (FARO, 1977, p. 201).

Fabregas defendeu-se das críticas por meio das colunas de $O$ País, afirmando que eram motivadas em decorrência da inimizade já relatada. No entanto, e provavelmente devido 
às fortes críticas recebidas, a peça obteve sucesso. O próprio Artur Azevedo, em crítica jornalística, relatou que o público "aplaudiu muito, muito, muito" (cf. FARO p. 202). A encenação obteve mais de quarenta representações, obtendo o prêmio de um conto de réis idealizado por Dias Braga, autor, ator e empresário que estipulou a premiação para as peças nacionais que ultrapassassem trinta representações seguidas. Em carta endereçada a Fabregas, Eça de Queirós demonstrou grande contentamento pela atenção e pela fidelidade do teatrólogo com a obra portuguesa. Segundo Eça, "nunca lhe parecera o Crime suscetível de dramatização. Acreditava que a isso só se prestava Os Maias" (p. 203).

Contudo, a representação de $O$ crime do Padre Amaro nos palcos foi caracterizada por sutis modificações no enredo original. De acordo com Faro, é provável que Eça de Queirós nunca houvesse sabido que a peça continha trilha sonora, que o papel de Amaro coube a Furtado Coelho, então com sessenta anos, e que o protagonista do romance acabava morto por João Eduardo, com um tiro nas costas (p. 203). Interessante também é que o autor português, provavelmente sem ao menos ter cogitado, recebeu $500 \$ 000$ réis relacionados aos direitos autorais. Ainda em 1890, surgiria uma versão cômica em torno do Padre Amaro. Nomeada A prisão do padre Amaro, "era um comentário teatral, um 'a propósito', em um ato, e foi representado pela primeira vez no dia 26 de maio de 1890, no Recreio Dramático. Escreveu-o João Campos Navarro de Andrade, jornalista e teatrólogo nascido em Portugal e que no Rio se radicou e morreu" (p. 204).

O Crime do Padre Amaro também recebeu crítica, nada favorável, por parte de Machado de Assis. O autor brasileiro, em artigo publicado no jornal O Cruzeiro, em abril de 1878 e sob o pseudônimo Eleazar, acusa Eça de Queirós de plagiar, através do Crime, a obra do francês Émile Zola intitulada La faute de l'Abbé Mouret, tradução aproximada “A falta do abade Mouret", a qual também apresenta como protagonista um padre. De acordo com Machado, através de $O$ Crime do Padre Amaro Eça revela não somente suas tendências literárias, mas também se revela "um fiel e aspérrimo discípulo do Realismo propagado pelo autor de Assommoir", ou seja, Zola:

O Crime do Padre Amaro é imitação do romance de Zola La Faute de L'Abbé Mouret. Situação análoga, iguais tendências; diferença do meio; diferença do desenlace; idêntico estilo; algumas reminiscências, como no capítulo da missa e outras; enfim, o mesmo título. O Sr. Eça de Queirós alterou naturalmente as circunstâncias que rodeavam o padre Mouret, administrador espiritual de uma paróquia rústica, flanqueado de um padre austero e ríspido; o padre Amaro vive numa cidade de província, no meio de mulheres, ao lado de outros que do sacerdócio só têm a batina e as propinas; vê-os concupiscentes e maritalmente estabelecidos, sem perderem um só átomo de influência e consideração. 
Nesse mesmo artigo, Machado de Assis também apresenta severas críticas a respeito do romance posterior ao Crime, O primo Basílio, publicado em 1878, em que considera a relação entre Basílio e Luísa "um incidente erótico, sem relevo, repugnante, vulgar”. O autor português não deixou de realizar sua réplica às críticas lançadas por Machado, produzindo um "escrito de defesa", intitulado "Idealismo e realismo", escrito, inicialmente, para compor o prefácio à segunda edição d'O Crime do Padre Amaro. No entanto, apenas fragmentos foram publicados junto à segunda edição. A integra da defesa de Eça seria publicada postumamente nas Cartas inéditas de Fradique Mendes, em 1879. Em seu escrito, Eça demonstra ter ciência das críticas de plágio que sua obra sofreu, tanto no Brasil como em Portugal. Em seguida, através de argumentos lógicos, põe em xeque as teses conspiratórias contra a originalidade das aventuras do padre Amaro com a afirmativa de que " $O$ Crime do Padre Amaro foi escrito em 1871, lido a alguns amigos em 1872, e publicado em 1874. O livro do Sr. Zola, La faute de L'Abbé Mouret, foi escrito e publicado em 1874” (FARO, 1977, p.169). Eça também aproveita a ocasião para utilizar brilhante ironia ao relatar a impossibilidade metafísica de "penetrar" na mente de Zola a fim de plagiá-lo para antecipar a obra que o francês, pouco tempo depois, produziria. O português apresenta uma série de descontruções acerca das passagens consideradas plagiadas, como fica evidente na seguinte passagem, em que há uma analogia entre o "paraíso" de Basílio e Luísa presente no Crime e o paraíso de Sérgio e Albina apresentado na obra de Zola:

O Paraíso, se por acaso leram e se lembram daquele meu livro, é um terceiro andar barato, para os lados da Bem-posta, alugado ao mês, onde uma senhora e um cavalheiro se vão amar duas vezes por semana, do meio-dia às três. O Paradou, como já disse, é aquela vasta e maravilhosa floresta, onde erram, quase nus, Sérgio e Albina, procurando, num instinto amoroso, a árvore iniciadora da ciência (QUEIRÓS, Eça de. Cartas Inéditas de Fradique Mendes, apud FERREIRA; FRAMBACH, p. 6).

De acordo com Eça, é evidente que "os críticos inteligentes que acusaram $O$ Crime do Padre Amaro de ser apenas uma imitação da Faute de L’Abbé Mouret, não tinham, infelizmente, lido o romance maravilhoso do Sr. Zola, que foi, talvez, a origem de toda a sua glória. A semelhança casual dos dois títulos induziu-os em erro".

\section{Considerações finais}

A partir dessa análise, foi possível evidenciar que a obra de Eça de Queirós, $O$ Crime do Padre Amaro, leitura constante no currículo escolar e nos processos de seleção dos vestibulares, já foi "trespassada" por diversos pontos de vista, variadas críticas e diferentes estágios de aprovação ou contradição que, hoje, deixam de ser abordados e apresentados aos 
leitores, aos alunos e a todos aqueles que, de certa maneira, têm contato com o estudo da literatura. A abordagem pura e simples de uma obra literária, olvidando ou ocultando sua trajetória em diferentes contextos, limita um conhecimento de maior amplitude a respeito do texto que nos é apresentado e, consequentemente, faz com que a historicidade e a riqueza contidas em uma obra permaneçam suspensas e desconhecidas.

O estudo e o ensino escolar dos autores literários e de suas obras, sendo avaliados sob distintas recepções, sejam essas temporais, históricas, geográficas, contribuem para o enriquecimento de um texto, colaborando diretamente para um olhar mais atencioso e construtivo por parte do público-leitor.

\section{Referências}

ASSIS, Machado de. Eça de Queirós - O primo Basílio. Obra completa de Macahdo de Assis, Rio de Janeiro, Nova Aguilar, vol. III, 1994 (http://www.machadodeassis.ufsc.br/obras/criticas/.htm).

FARO, Arnaldo. Eça e o Brasil. São Paulo, Editora Nacional, Ed. da Universidade de São Paulo, 1977.

FERREIRA, Nádia Paulo; FRAMBACH, Lídia Bantim. Polêmica entre Machado de Assis e Eça de Queirós (http://www.omarrare.uerj.br/numero13/pdfs/alfarrabios.pdf)

LOBO, Luiza. Leitor. In: JOBIM, José Luís. Palavras da crítica. Rio de Janeiro. Imago, 1992.

Estética da recepção. In: SAMUEL, Rogel. Manual de Teoria Literária. Petrópolis: Vozes, 2001.

QUEIRÓS, Eça de, 1845-1900. O Crime do Padre Amaro. São Paulo: Companhia Editora Nacional, 2004.

ZILBERMAN, Regina. Estética da recepção e história da literatura. São Paulo: Ática, 1989. 